\title{
The Symbol Made Text: Charles Palliser's Postmodernist Re-Writing of Dickens in The Quincunx*
}

\author{
Susana Onega \\ University of Zaragoza
}

\begin{abstract}
Early reviewers of The Quincunx (1989) immediately recognised the novel's striking stylistic and thematic indebtedness to Dickens and to other early Victorian writers, a fact that led them to describe Charles Palliser's first novel as a brilliant attempt to reproduce an early Victorian novel. However, closer examination reveals that The Quincunx is not merely a belated imitation of Victorian fiction, but rather a neatly structured, symbolically complex and highly self-conscious parody of it, in line with other contemporary historiographic metafictions, like The French Lieutenant's Woman or The Name of the Rose, and expresses Palliser's own postmodernist world-view.
\end{abstract}

Charles Palliser's first novel, The Quincunx: The Inheritance of John Huffam won immediate recognition and nearly universal praise upon its publication in 1989 in the United Kingdom by Canongate and in 1990 in the United States by Ballantine Books. The novel, which was twelve years in the writing, preceded by four years in gestation, was short-listed for three literary awards in the U. K. It won the 1991 Sue Kaufman Prize for First Fiction, awarded by the American Academy and Institute of Arts and Letters. Clearly, the book struck a resounding chord. One is entitled, then, to ask exactly what was its resonance.

Early British and American reviewers of The Quincunx immediately recognised the novel's striking Dickensian quality, whose hero, John Huffam, not only bore Dickens' own middle names but was, like Dickens, born on 7th February 1812 (the birth year is never explicitly mentioned, but it can be deduced from the reference in Huffam's baptism record (333) to the conquest of Ciudad Rodrigo (19th January 1812) by Sir Arthur Wellesley (i.e.

* The research carried out for the writing of this paper has been financed by the Spanish Ministry of Education (DGICYT, Programa Sectorial de Promoción General del Conocimiento, no. PS90-0117). 
Lord Wellington) a few days before John's birth). Apart from Dickens, the critics also pointed out the echoes of other Victorian writers like Wilkie Collins (Craig, 1990: 34, Drabelle, 1990: O2D), Thackeray, Trollope, Hardy (Lehemann-Haupt, 1990: 8D), George Elliot and Robert Surtees (Espey, 1990: 3C), a fact that has led some of them to support the The Independent's view that Palliser's first novel is "a brilliant attempt to reproduce an early Victorian novel" (Baldwin, 1990: A30).

However, closer examination reveals that the novel is not merely an imitation of Dickens, or any other Victotian writer. As the author himself insists, Dickens and Palliser have "totally different way[s] of seeing the world" (Baldwin, A30), and indeed they must, for they belong to two different eras with widely divergent cosmovisions. The Quincunx, like John Fowles' The French Lieutenant's Woman, Peter Carey's Oscar and Lucinda, Jean Rhys' Wide Sargasso Sea and Umberto Eco's The Name of the Rose, with which Palliser's novel has also been compared (Griffith, 1990: NO8; Marcus, 1990: 24; Stephenson, 1990: E12; Walton, 1990: HO1), is a good example of what Linda Hutcheon has called "historiographic metafiction." Hutcheon uses this term to describe "those wellknown and popular novels which are both intensely self-reflexive and yet paradoxically also lay claim to historical events and personages" (5).

According to Hutcheon, this unique combination of self-reflexivity and history in historiographic metafiction perfectly expresses what is for her the defining characteristic of the Postmodernist ethos: its basically contradictory nature. Like metafiction, historiographic metafiction cuts the link between fiction and reality, underlining its discursive and fictional nature. Like history, historiographic metafiction simultaneously asserts the interrelation of fiction to the historical past, even though, in accordance with the New Historicism, historiographic metafiction questions the capacity of history to reveal absolute truths. Characteristically,

Those un-innocent paradoxical historiographic metafictions situate themselves within historical discourse, while refusing to surrender their autonomy as fiction. And it is a kind of seriously ironic parody that often enables this contradictory doubleness: the intertexts of history and fiction take on parallel status in the parodic reworking of the textual past of both the "world" and literature. (Hutcheon, 1988: 124; my italics)

Or, historiographic metafiction expresses a pradoxical "longing for the return to the traditional relish in story telling [of the realist novel], while simultaneously underlining the fact that this return is problematic" (Hutcheon 124-25).

The Quincunx grows splendidly out of this apparent contradiction. On the one hand, the novel has all the ingredients of the traditional realist novel: a young boy, John Mellamphy, and his mother are living in reduced but genteel circumstances in the rural north of England in the 1820s. John soon realises that his mother, Mary, is hiding from "an enemy" whose effects are felt when Mrs. Mellamphy is lured into investing in a land speculation scheme which proves to be a fraud and reduces them to poverty. Then, discovered by the agents of her enemy, she flees with John to London, where they begin a life of progressive degradation with their pursuers at their heels. Finally, in the vein of melodramatic realism, John discovers that his name is not really Mellamphy, but Huffam 
and that he is entitled to inherit one of the largest estates in England. This is why he and his mother are constantly sought and threatened with violent death.

The settings, character depiction, historical background and even style in which this fabula is set are wonderfully accurate. As we follow John Huffam's quest, we see the horrible squalor in which the poor lived in London in the early eighties as well as the social and political structures and attitudes that made these social conditions possible. The realism and accuracy with which all these elements are displayed reassuringly function to enhance the reader's "willing suspension of disbelief." On the other hand, the episodes that make up John Huffam's quest simultaneously appear as pastiche-ridden and openly literary, as they strongly recall similar episodes in well-known Victorian novels, effectively working to undermine the illusion of credibility of the created world. M. Malone (1990: 12), among others, has pointed out the parallelisms existing between crucial episodes in Dicken's novels and in The Quincunx where

we meet the strange young gilr in a great crumbling estate, the floating prison hulks and mysterious legacy of Great Expectations; the debtor's prison and supressed codicil of Little Dorrit; the heir's convoluted name change and presumed death by drowning of Our Mutual Friend; the loathsome father-son business team and the vast real-estate development scam of Martin Chuzzlewit; the stormy night, carriage chase and foiled elopement of The Pickwick Papers; the pauper child of secret parentage kidnapped by a gang of thieves of Oliver Twist.

Malone further observed that, "[i]n addition, Mr. Palliser seems to be deliberately trying to outdo Dickens in replays of specific scenes [like that of] the sadistic boarding school [taken from] Nicholas Nickleby," so that "Mr. Palliser appears to have set out not merely to write a Dickens novel but to write all Dickens novels." In short, Malone believes Palliser to have set out to parady Dickens rather than imitate him.

But this observation, however defensible, misses the larger point. In The Quincunx, Palliser combines history and literature suggesting the possibility of equalizing the versions of reality they offer, levelling them to the same (literary) status. This combination of realism-enhancing and realism-undermining elements echoes Palliser's own description of George Eliot's “attempt [in Adam Bede] to reconcile reality and art by an ironic alternation between reassuring and disconcerting the reader" (1980: 76). It also expresses a desire for plurivocity, for the acceptance of alternative and complementary versions of reality. This desire for plurivocity is best synthesised in the complex unities of the novel's unifying symbol: the quincunx.

At the front of the building intended by John's great-great grandfather, Jeoffrey Huffam, to be a mausoleum, near the Old Hall of the Huffam estate, John finds an arrangement of five trees and five marble statues from which the central tree and statue had been removed. He learns that this pattern, called "quincunx," is a reproduction of the pattern of the original Huffam shield: an arrangement of five quatrefoil roses like the five on a die, from which the shields of the other branches of the Huffam family derive.

Ian MacNiven, in analysing The Avignon Quintet, that other wonderful quincunx of novels, has explained the meaning of the quincunx of trees as "a planting pattern not 
uncommon in medieval and Renaissance arboretums: five trees arranged like the dots on the five dominoes. This quincunx of trees is said to be like the lost Templar treasure [which can be either] a treasure of gold and precious stones [or] a gem of spiritual knowledge, a gnosis" (235).

Steven Marcus' interpretation of the quincunx as "an arrangement of five objects often used in heraldic devices whose meaning expands as five branches of the same clan struggle over a patrimony" (1990: 24) is perfectly adequate at the surface level. John Huffam's quest certainly involves the discovery of the links connecting the five branches of the Huffam family and the establishment of his own relationship to them. Indeed, the novel ends when John Huffan achieves the reconstruction of a quincunx of quincunxes formed by the shields of the five family branches. Huffam himself as the heir occupies the central position.

Palliser is at pains to emphasize this quincunx symbology. Besides the single quincunx of trees and statues with the vacant centre symbolising the absence of a Huffam heir, John also finds a quincunx of quincunxes at the Huffam estate. The floor of the Old Hall makes a "pattern of black and white tiles making black and white lozenges like endlessly proliferating and ramifying quincunxes" (742), whose centre, as John interestingly remarks, "changed as I advanced." This quincunx of quincunxes anticipates the heraldic quincunx of quincunxes formed by the combination of shields of the five family branches made of black iron and white marble that John finds on the entablature of the mantlepiece of the Great Parlor in the Mompesson mansion in London and which is " $a$ machine infernale, a booby-trap" (662) protecting the safe that keeps the will that would make John the rightful owner of the Huffam estate. By guessing the right arrangement of quatrefoil rose buds representing the different family branches in this quincunx of quincunxes, John is able to open the safe hidden in the entablature above the mantelpiece and so, literally, to find the key to his lost tresure.

The interpretation of the quincunx admits further symbolic interpretation. In both the pythagorean and the cabalistic symbolic systems, the number five is one of the divine numbers. Pythagorean numerology holds that the number five is the numerus aureus, the golden number, symbolising both the harmonic growth of man in a living nature and man's parallel spiritual development and maturation. According to cabalistic gematria, five symbolises the materialization of God's blessing. In Hebrew the number is represented by the letter $\mathrm{H}$, which appears twice in God's name $=\mathrm{IHVH}$, thus becoming the letter added by God himself to Abraam's name after his blessing = Abraham (Genesis 17,5). Further, used as emblem by Sir Gawain in the form of "pentalpha" or five-pointed star, the number five symbolises human perfection (Esteban Lorente, 1990: 68).

In this light, John Huffam's quest does not end with the opening of the safe and the recovery of his inheritance. Like the medieval and Renaissance quester, his quest is twofold, involving both the acquisition of wealth and the recovery of his lost identity as a prerequisite for his moral and psychological maturation. This psychological or spiritual aspect of the quest is symbolised in yet another version of the quincunx devised by John's ancestor, Jeoffrey Huffam, who tried to identify the quincunx and the Huffam name in constructing the big new house on the Huffam estate, which is intended to "take the form of and ' $\mathrm{H}$ ' . . to celebrate his own name" (563). As cabalistic symbology makes clear, 
Jeoffrey Huffam's statement that the H stands for his own name can be read as a hint of the divine nature of John's ancestor. This interpretation is bolstered by the intertwined facts that Jeoffrey Huffam's arch-enemy, originally called Abraham (see above), changed his name to Nicholas (630) (a familiar equivalence with Satan) and that this Nicholas fathered John Huffam's own devil-like enemy, Silas Clothier, a mony-lender in the literary tradition of the greedy Jew. Thus at this level, John Huffam's quest acquires metaphysical overtones, becoming the archetypal Son's struggle for atonement with the Father, and so, Man's striving for spiritual knowledge (gnosis) in order to become Cosmic Man or Anthropos.

John's spiritual quest is assisted by a pair of "Punch and Joan" puppeteers, Mr. Pentecost and Mr. Silverlight, who try to teach John their respective visions of society and literature, that is, of the historically "real" and of the "unreal," of "truth" and "art." Mr. Pentecost is a convinced Hobbesian and Utilitarian and therefore believes that the governing principles in the world are self-interest and the Law of Necessity. Pentecost-whose name surely suggests some fiery reactionism--believes that the ideas are determined by economic circumstances and that the Law is no more than an arbitrary construction designed to protect the wealthy and oppress the poor. He also believes that pauperism is necessary to society and so fatalistically proposes the abolition of charity and the subjection of labour to the self-regulating mechanism of the free-market. Accordingly, life is random and arbitraty, hiding no overall pattern of meaning. Mr. Silverlight, on the other hand, is a Deist and a Radical Democrat and in accordance with his name believes in reason as the ordering principle of society. By the application of reason man can discover the overall design that knits the Universe together, and which proves the existence of a Supreme Spirit of Reason. Reason, and not self-interest, forms the ordering principle upon which society is founded, and, if well applied, can improve justice and society to the point of perfection. During one of their endless discussions, Pentecost and Silverlight toy with the idea of writing a novel for, as Pentecost insists (and Silverlight admists), "there is more truth in the silliest romance than in the most elevated history" (240). For Pentecost, the only thing that matters in a novel is the plot itself, what the characters do, while for Silverlight action is meaningless without the motives that would help the reader draw the overall design underlining the character's actions. As Miss Quilliam, Henrietta's ex-governess, comments, Pentecost's and Silverlight's views on fiction "are complementary rather than in conflict"'(240), and she suggests that they should collaborate:

So perhaps you should collaborate. Mr. Silverlight could take responsibility for describing the motives of the characters (partucularly, of course, in the upper ranks) while you, Mr. Pentecost, could concentrate [sic] your talents upon the elements of plotting and intrigue. (240)

Silverlight's condition for his collaboration is that "[i]n every novel I collaborated upon everything would be a part of a whole design-down even to the disposition and numbering of the chapters" (240). This remark proves to be a very disingenuous metacomment, for as soon as we start reading The Quincunx, we find that the puppeteers' 
project has indeed become an actuality, and that "even the disposition and numbering of the chapters" has been subjected to a careful arrangement. The novel combines chapters narrated by five-a quincunx-major narrative instances: the puppeteers; John Huffam; his mother, Mary; Miss Quilliam and Mr Escreet.

John's narration forms the bulk of the novel and may be described as the restrospective "confession" of an internal narrator whose knowledge is limited to his own perspective. This "confession" is addressed to the puppeteers, as we eventually learn (772). The chapters narrated by Miss Quilliam and Mr. Escreet are likewise retrospective and focalised "confessions," with John Huffam as their addressee. Mary's narration takes the form of a written account aimed in principle at informing John of basic events that took place in her past but which progressively develops into a "diary" aimed at herself rather than at her son. The puppeteers' chapters are structured like the short scenes in a pantomime. They all have John as a narratee, as we also eventually learn $(725,755,756)$ although, apparently, some chapters are narrated by both puppeteers and some by either of them in isolation. In the chapters narrated by Silverlight, the most powerful and aristrocatic characters are allegorised and made to represent the abstract principle that motivates his or her actions. Thus, for instance, an attorney becomes "Law," a member of the High Court of Chancery, "Equity," a solicitor, "Power," an aristocratic lady, "Arrogance." In those narrated by Pentecost, the same characters are called by their names and the narration is concentrated on the things they have done, are doing or propose to do, without ever attempting to 'speculate' on the motives behind their actions.

The novel's overall structure echoes the Huffam heraldic quincunx of quincunxes: the novel is divided into five Parts, each consisting of five Books with five chapters each. These chapters are arranged following two heraldic principles: that of mise en abyme, or "shield within the shield" structure, according to which the centre can multiply itself in infinitum, and that of the diagonally mirrored reflection that John found governing the arrangement of colours in Miss Lydia's reproduction of the heraldic quincunxes uniting the Mompesson and Huffam families (661). Accordingly, in Part One the puppeteers narrate the first chapters of Book I (ch. 1) II (ch. 6), IV (ch. 16) and V (ch. 21) and John narrates the remaining four. The Book occupying the centre, Book III, reverses this arrangement: John narrates the first chapter (ch. 11) and the puppeteers the remaining four (chs. 12, 13, 14 and 15). Parts II, IV and V are arranged symmetrically, but following the heraldic principle of the diagonal mirrored reflection. So, Part Five, diagonically opposed to Part One, has exactly the same structure, with the puppeteers narrating the first chapters of Books I, II, IV and V and John the remaining four chapters and, inversely in Book III, with John narrating the first chapter and the puppeteers the remaining four. Parts Two and Four retain the same structure in Books I, II, IV and V but in Book III John's narration does not alternate with that of the puppeteers but with that of a third narrator: in Book III of Part Two John narrates the first chapter (no. 36) and Miss Quilliam the remaining four (chs. 37, 38, 39 and 40), while in Part Four it is Mr Escreet who narrates the equivalent of these (chs. 87, 88, 89 and 90). The five Books in Part Three, are devoted to Mary's diary. Books II, III and IV are arranged like the equivalent books in the other four Parts, but Books I and V are different from any other: Book I is divided into five "relations," that 
is, contains another quincunx en abyme, while Book V reflects Book I in the reverse, by containing five blank "relations," the five missing entries in Mary's diary.

When Miss Lydia, John Huffam's "first cousin twice removed" (630), gives John the ancient invitation to a ball that reproduces the heraldic pattern of the quincunxes uniting the Mompesson and Huffam families, he realises that each quincunx combined "three tinctures--white, black and red" and that " $[t]$ he crucial central quincunx was identical to the second and the fourth, except that the bud of the middle quatre-foil appeared-as predicted-not to be white. Baut was it? ... it was very difficult to make out whether the central bud was filled with dots or was entirely black-or was even white after all but marked with slight discolorations of the paper" (671). John's uncertainty about the real colour of the central bud accurately reflects the symbolic characteristics of the centre of the quincunx. According to Jung, the centre of the quincunx is the umbilicus mundi, the origin of everything, characterised as the "innefable," as what cannot be explicitly or even implicitly expressed. Consequently, the centre contains infinite centres and can never be perfectly located, for it changes according to the position of the observer, endlessly multiplying itself in a mise en abyme in infinitum, as happened to the black and white pavement of the Old Hall when John walked along it (742). Or again, as happens to John when, contemplating the ravaged and time-worn countenance of the marble figure that had originally stood at the centre of the mausoleum, he was struck by the hidden layers of meaning he could read "from that palimpsest of a face" endlessley receding, "like the tiles of the broken floor of the Old Hall" (774).

Following the symbology of the centre with remarkable accuracy, Mary's diary occupies the five-not just four-chapters of Book III of Part Three, that is, the whole central Part, and so of the novel. It is arranged as a self-contained quincunx, with its own subdivisions and diagonal mirrored reflections. Chapter 61 is subdivided into five "relations" while its symmetrical reflection, chapter 65 , opposes this cramming or filling up of chapter 61 (comparable to heraldic "tincturing" or colouring) by containing five blank or empty entries, (corresponding to white or colourless in heraldry). The structure of Mary's diary, therefore, like the central bud in the heraldic quincunx of quincunxes is simultaneously black and white, accurately reproducing the baffing regressus in infinitum structure of the centre that suggests the illusion of a centre for the whole novel, and so, of unitary meaning, and the absence of a centre, and so, of infinite variations of meaning (see fig. 1).

Returning now to the question of character, John, throughout the novel, has insistently searched for the motives underlying his enemies' actions and has also submitted his own thirst for justice and redress to a close scrutiny. Following Mr. Silverlight's advice, he has asked himself whether all his apparent concern with justice really only hid an unconscious desire for comfort and wealth. In chapter 115, before taking leave of John Huffam, Mr. Silverlight once again reminds his pupil that human motivation is very complex and that "[e]ven what appears to be a dishonourable action, if properly understood, may be revealed to be wholly just." He then entreats John to "judge your own motives as only you are able. Then if you are sure your motives are pure, you may entrust yourself with Wealth and Power," urging upon him, "in conclusion, the Universal Duty to seek Justice and so gain the means to exercise Philantropy" (725). In the following chapter, however, 


\begin{tabular}{|c|c|c|}
\hline $\begin{array}{l}\text { Book I } \\
\text { ch } 1 \text { proppetees } \\
\text { ch } 2 \text { John } \\
\text { ch } 3 \text { John } \\
\text { ch } 4 \text { John } \\
\text { ch } 5 \text { Johm }\end{array}$ & & 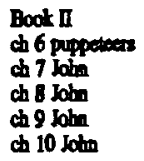 \\
\hline & 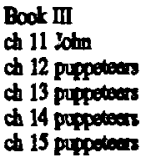 & \\
\hline $\begin{array}{l}\text { Book IV } \\
\text { ch } 16 \text { poppeseos } \\
\text { ch } 17 \mathrm{John} \\
\text { ch } 18 \mathrm{John} \\
\text { ch } 19 \mathrm{John} \\
\text { ch } 20 \mathrm{John}\end{array}$ & & $\begin{array}{l}\text { Boot V } \\
\text { ch } 21 \text { puppeat } \\
\text { ch } 22 \mathrm{John} \\
\text { ch } 23 \mathrm{Johm} \\
\text { ch } 24 \mathrm{John} \\
\text { ch } 25 \mathrm{John}\end{array}$ \\
\hline
\end{tabular}

\begin{tabular}{|c|c|c|}
\hline \multicolumn{2}{|c|}{$\begin{array}{l}\text { Book I } \\
\text { ch } 26 \text { puppotear } \\
\text { ch } 27 \text { Jom } \\
\text { ch } 28 \text { John } \\
\text { ch } 29 \text { John } \\
\text { ch } 30 \mathrm{Jahn}\end{array}$} & $\begin{array}{l}\text { Boot II } \\
\text { ch } 31 \text { poppotens } \\
\text { ch } 32 \mathrm{John} \\
\text { ch } 33 \mathrm{John} \\
\text { ch } 34 \mathrm{John} \\
\text { ch } 35 \mathrm{Jahe}\end{array}$ \\
\hline & \multicolumn{2}{|c|}{$\begin{array}{l}\text { Book III } \\
\text { ch } 36 \text { Joho } \\
\text { ch } 37 \text { Miss Qudllim } \\
\text { ch } 38 \text { Miss Quillimm } \\
\text { ch } 39 \text { Miss Qudllimm } \\
\text { ch } 40 \text { Miss Quilliem }\end{array}$} \\
\hline $\begin{array}{l}\text { Rook IV } \\
\text { ch } 41 \text { puppeloos } \\
\text { ch } 42 \text { Jahn } \\
\text { ch } 43 \text { bolm } \\
\text { ch } 44 \text { bohn } \\
\text { ch } 45 \text { Jahn }\end{array}$ & 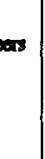 & $\begin{array}{l}\text { Book V } \\
\text { ch } 46 \text { puppotecis } \\
\text { ch } 47 \text { John } \\
\text { ch } 48 \text { John } \\
\text { ch } 49 \text { Jabn } \\
\text { ch } 50 \text { Jahn }\end{array}$ \\
\hline
\end{tabular}

\section{PART THREE}

\begin{tabular}{|c|c|c|}
\hline $\begin{array}{l}\text { Book I } \\
\text { ch } 51 \text { puppetears } \\
\text { ch } 52 \text { John } \\
\text { ch } 53 \text { Jabn } \\
\text { ch } 54 \text { John } \\
\text { ch } 55 \text { John }\end{array}$ & & $\begin{array}{l}\text { Book II } \\
\text { ch } 56 \text { puppotes } \\
\text { ch } 57 \text { John } \\
\text { ch } 58 \text { John } \\
\text { ch } 59 \text { John } \\
\text { ch } 60 \text { John }\end{array}$ \\
\hline & $\begin{array}{l}\text { Book II } \\
\text { ch } 61 \text { (5 rolations) } \\
\text { ch } 62 \text { Mary } \\
\text { ch } 63 \text { Mary } \\
\text { ch } 64 \text { Mary } \\
\text { ch } 65 \text { ( } 5 \text { blanks) }\end{array}$ & \\
\hline $\begin{array}{l}\text { Book N } \\
\text { ch } 66 \text { puppeters } \\
\text { ch } 67 \mathrm{Jahn} \\
\text { ch } 68 \mathrm{John} \\
\text { ch } 69 \mathrm{Jahn} \\
\text { ch } 70 \mathrm{John}\end{array}$ & & $\begin{array}{l}\text { Book V } \\
\text { ch } 71 \text { pupreters } \\
\text { ch } 72 \text { John } \\
\text { ch } 73 \text { John } \\
\text { ch } 74 \text { John } \\
\text { ch } 75 \text { John }\end{array}$ \\
\hline
\end{tabular}

\section{PART FOUR}

\begin{tabular}{|c|c|c|}
\hline 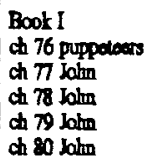 & & 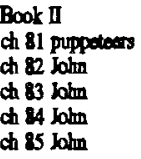 \\
\hline & $\begin{array}{l}\text { Booi III } \\
\text { ch } 86 \mathrm{Jbm} \\
\text { ch } 87 \mathrm{Mr} \text { Escreat } \\
\text { ch } 88 \mathrm{Mr} \text { Bscreat } \\
\text { ch } 89 \mathrm{Mr} \text { Bccred } \\
\text { ch } 90 \mathrm{Mr} \text { Escreet }\end{array}$ & \\
\hline $\begin{array}{l}\text { Book II } \\
\text { ch } 81 \text { propeteen } \\
\text { ch } 82 \text { John } \\
\text { ch } 83 \text { John } \\
\text { ch } 84 \text { John } \\
\text { ch } 85 \text { bohn }\end{array}$ & & $\begin{array}{l}\text { Book V } \\
\text { ch } 96 \text { puppeteers } \\
\text { ch } 97 \mathrm{Jahn} \\
\text { ch } 98 \mathrm{lolm} \\
\text { ch } 99 \mathrm{Jahn} \\
\text { ch } 100 \mathrm{Johs}\end{array}$ \\
\hline
\end{tabular}

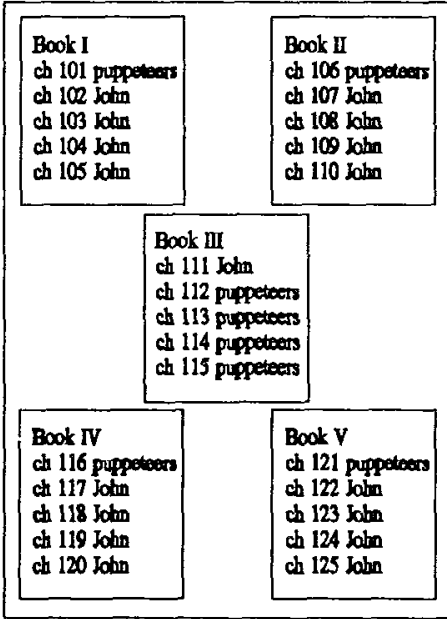


Mr. Pentecost dismisses Silverlight's philantropic cant with a characteristic "Fiddlesticks!" (727). With this, the novel closes leaving John Huffan reluctantly considering his possibilities: devoting the rest of his life to the use of the ill-gotten wealth of his arch-enemy, Silas Clothier, to which he is also entitled, reconstructing the now pitifully decayed Huffam estate; or renouncing his inheritance. This ending may be interpreted simply as a teasing decision of Palliser to leave the novel open-ended, but it also allows for more interesting interpretations. By growing beyond the impulses of Hobbesian self-interest and by being ready to renounce the comfort of wealth and aristocratic preferment, John Huffan is proving that he has succeeded not only in the material, but also in the spiritual side of his hero's quest, and so, that, like the Templar quester, he has been granted the treasure because he has proved capable of using it well. Then, too, at a metatextual level, John Huffam's doubts about whether or not to accept the Huffam "inheritance" may be read as a hint of Palliser's "anxiety of influence," of his awareness that he cannot accept the "inherintance of Charles Dickens" without a clear awareness of his real motives and purpose.

As the novel ends, the reader is left with the comforting conviction that John's and the other narrator's complementary versions of events have finally cohered like the pieces of a puzzle, into a perfectly plausible and comprehensive version of the whole. John has found the hidden connections that link together the members of the five Huffam branches and has established his own central position in the overall pattern. However, the reader is also aware that some threads have been left untied, that many contradictory versions have been allowed to coexist unchecked. For example, the radical Hobbesian, Mr. Pentecost, paradoxically practices a hushed and bashful kind of charity with an ex-radical convict turned blind beggar, called Justice. He is eventually sent to prison, where he dies, for having acted against the principle of self-interest, by backing a bill for a friend who was heavily in debt as a consequence of playing at Hazard. This friend might be Silverlight himself who believes that conscience and reason should be the ruling principles governing human relationships. Yet he was ruined playing at Hazard and is further revealed to be the treacherous radical who betrayed Justice and who also probably was the agent who pointed out Mr. Pentecost's hiding place to the sheriff's officers. As another example, we know that Mr. Pentecost died at the Fleet even before Mary's own death (245, 440 and 458). However, at the end of the novel John Huffam says that Mr Pentecost might still be in the Fleet (770) and is going to ask him to collaborate with him and Silverlight in the writing of the very novel we have in our hands, which, as we know, he does.

So, how are we to accept the metafictional fact that Pentecost as character may be dead while Pentecost-as narrator-may be still alive? To say nothing of the disturbing possibility, as avowed co-authors of the novel, the puppeteers and John Huffam might have written themselves into existence? Even if we imagine a god-like puppeteer behind the puppeteers, how are we to explain the existence of loose threads and incoherences in a novel whose author has proved capable of the most exquisite design? Surely we cannot attribute them to oversight, for, as John ironically remarks: "[i]f there was an Author arranging my life, I could not think so ill of himn" (483). A better explanation therefore, would be to say that the loose threads, the blurring of ontological boundaries, the striking coincidences and contradictions in the novel are there to remind the reader of the banality 
of trying to explain human actions in reductionist rational terms. As Pentecost insists: " $[t]$ he concatencation of events is always more complicated and inexplicable than we like to imagine. We must rememberthat a pattern-whether of the past or the future-is always arbitrary or partial in that there could always be a different one or a further elaboration of the same" (755). This is precisely the explanation Palliser himself offered when asked about his intended meaning for the "quincunx":

Its point is what is explained in the novel: it's both highly designed and yet in another sense accidental in that it occurs whenever there are squares-as on a chess-board or a paved floor. So it gramatises ideas about pattern and randomness. But I think a novel is like a complicated toy that can be used for lots of things that its inventor never imagined, so if people want to read it in [an archetypal] sort of way I'm perfectly happy to let them. (Letter to Onega, 1991, Nov. 30)

Palliser's definition of the quincunx thus echoes the quintessential dual symbolism of the centre while his conception of the novel as a complicated toy that can be used for things the inventor never imagined brings to mind the postmodernist contention that the literary text, like reality itself, can never be totally pinned down and that one of the freedoms it allows is the individual freedom to "misread" it, to adjust its message to the individual imagination. If The Quincunx is an imitation of the Victorian novel, then, it is an imitation with a difference, the difference that lies between the Victorian and the Postmodernist cosmovisions, between the realism-enhancing, univocal and neatly designed version of the world offered by the Victorian writers and the openly fictional, inconclusive, relativist and plurivocal version of it offered by the twentieth-century novel.

\section{Works Cited}

Baldwin, J. “Novelist Hits Jackpot with Homage to Dickens” New Orleans Times Picayune June 1990: A30.

Drabelle, D. “The Dickensian Charm of Colossal Quincunx.” USA Today January 1990: 02D.

Espey, J. "Fiction-The Past Recaptured: A Modern Writer Recreates the Rich Textures of 19th Century Fiction." Chicago Tribune January 1990: 3C.

Esteban Lorente, J. F. Tratado de iconografia. Madrid: Fundamentos, 1990.

Griffith, B. “Twists of Quincunx Tease Midn, Touch Emotions." Atlantis Journal February 1990: N08.

Hutcheon, L. A Poetics of Postmodernism: History, Theory, Fiction. New York and London: Routledge, 1988.

Leheman-Haupt, C. "Weighty Quincunx Ideal for the Compulsive Reader." St. Paul Pioneer Press Dispatch March, 1990: 8D.

MacNiven, I. S. "The Quincunx Quiddified: Structure in Lawrence Durrell." The Modernists: Studies in a Literary Phenomenon. Rutherford: Fairleigh Dickinson University Press, 1987. 234-248.

Malone, M. "The Spirit of Dickens Present." New York Book Review March 1990: 12.

Marcus, S. “Dickens on an Epic Scale," Newsday February, 1990: 25. 
Palliser, C. "Adam Bede and "The Story of the Past."' George Elliot: Centenary Essays and an Unpublished Fragment. Ed. Anne Smith. London: Vision Press, 1980. 55-76. . The Quincunx: The Inheritance of John Huffam. Edimburgh: Canongate, 1989. Stephenson, A. "Hardcover Fiction." Arizona Republic January, 1990: E12. 